\title{
Proximate Composition, Minerals and Amino Acids Profiles of Selected Wild Edible Russula Species from Côte d'Ivoire
}

\author{
Kouamé Appolinaire Kouassi, Kouassi Hubert Konan*, Eugène Jean Parfait Kouadio, \\ Ahipo Edmond Due, Lucien Patrice Kouamé.
}

Laboratoire de Biocatalyse et des Bioprocédés de l'Université Nangui Abrogoua (Abidjan, Côte d'Ivoire), 22 BP 801 Abidjan 22, Côte d'Ivoire A R T I C L E I N F O

A B S T R A C T

Article history:

Received 01 June 2016

Accepted 06 September 2016

Available online, ISSN: 2148-127X

Keywords:

Amino acid composition

Mineral composition

Proximate composition

Russula

Wild mushrooms.

${ }^{*}$ Corresponding Author:

E-mail: h_k_konan@yahoo.fr

\begin{abstract}
Some wild edible mushrooms of genus Russula are consumed in the center region of Côte d'Ivoire. In this study, the proximate composition, mineral element and amino acid profile of three selected wild edible Russula species from Center of Côte d'Ivoire including Russula delica, Russula lepida and Russula mustelina were investigated. The mushrooms were harvested fresh, dried in an oven at $45^{\circ} \mathrm{C}$ for 48 hours, ground and analyzed according to standard procedures. Proximate analysis showed high level of proteins $(38.08 \pm 0.29-38.52 \pm 0.23 \%)$, crude fibre $(9.59 \pm 0.21-19.78 \pm 0.7 \%)$, carbohydrate $(39.29 \pm 1.71-41.64 \pm 1.41 \%)$, ash $(12.7 \pm 0.16-13.80 \pm 0.10 \%)$ and fat $(4.06 \pm 0.11-$ $5.70 \pm 0.05 \%)$ in all species. Mineral analysis of all species indicated that the mushrooms were specifically rich in potassium, phosphorus, calcium and magnesium. $R$. delica contained the highest level of calcium and phosphorus. The mushrooms contained 18 amino acids among with the most predominant ones in all species were glutamic acid and valine. In addition, the ratios of essential amino acids to total amino acids were between 0.40 and 0.45 . The high scores of essential amino acids present in these mushrooms implied that they have a high biological protein value. These mushrooms could be considered as a potential health food and may be of use to the food industry as a source of ingredients with high nutritional value.
\end{abstract}

\section{Introduction}

Mushroom is a general term used mainly for the fruiting body of macrofungi (Ascomycota and Basidiomycota) and represents only a short reproductive stage in their life cycle (Das, 2010). Total mushrooms on the earth are estimated to be 110,000 species in which $10 \%$ (14,000 approximately) are known (Hawksworth, 2001). Among these, 7750 macrofungal species are known to have ectomycorrhizal nature (Rinaldi et al., 2008). These mushrooms form mutual symbiotic association with forest trees, which is most important for their growth, nutrient absorption and protection of roots from pathogens (Marx, 1997). The genus Russula is cosmopolitan and an ectomycorrhizal genus is associated with a wide range of Gymnosperms and Angiosperms (Molina and Trappe, 1982; Kraiger et al., 1995; Agerer, 2002), thus creating distinct features in roots of forest trees. These characters are preferentially dependent, influenced and fashioned by the fungal hyphae of these essentially important structures of the root system (Agerer, 2002).

Mushrooms have been found to be nutritious and important for medicinal purposes (Manzi et al., 1999;
Jonathan and Fasidi, 2005; Gbolagade et al., 2006). They have been considered as rich food because they contain proteins, sugars, glycogen, lipids, vitamins, amino acids and crude fibres. They also contain important mineral nutrients, which are required for normal functioning of the body (Kuforiji et al., 2003). A large number of Russula species are better known for their antimicrobial and antioxidant activities and thus having medicinal significance (Mercan et al., 2006; Liu, 2007; Jain and Pande, 2013).

In Côte d'Ivoire, wild edible mushrooms are known and consumed in many households. In rural areas where they are abundant, most people collect them for home consumption as well as for extra income (Koné et al., 2013).

Despite the economic importance of these wild edible mushrooms in the collecting area (Center of Côte d'Ivoire), there was any study which has been carried out on their nutritional values. In this study, we have examined the nutritional quality of three wild edible mushrooms, i.e. Russula delica; Russula lepida, and Russula mustelina from center region of Côte d'Ivoire. 


\section{Material and Methods}

\section{Raw Materials}

The sporocarps of genus Russula were collected from their natural habitat at various locations across center region of Côte d'Ivoire between July 2013 and June 2014. The type of vegetation at the sites of collection consisted of a typical clear forest. Taxonomic identification was achieved by Dr Souleymane Yorou Nourou (Abome Calavy University of Benin/ Munich University of Germany), as R. lepida, R. mustelina and R. delica.

\section{Sample Preparation}

Mushrooms were first washed thoroughly to free from mud, ferns and other extraneous material, dried on blotting paper and cut into pieces. The mushrooms selected are normally harvested for consumption without division into pileus and stipe. Therefore, the whole mushrooms (pileus + stipe) after washing, were dried in an oven at $45^{\circ} \mathrm{C}$ for 48 hours. The dried samples were mechanically milled into powder with flat-hammer grinding mill and sifted through a 60-mesh screen and then stored in airtight containers for analysis (AOAC, 1995).

\section{Proximate Composition Analysis}

Dry matters were determined by drying in an oven at $105^{\circ} \mathrm{C}$ during $24 \mathrm{~h}$ to constant weight (AOAC, 1990). Crude protein was calculated from nitrogen $(\mathrm{Nx} 6.25)$ obtained using the Kjeldahl method by AOAC (1990). Crude fat was determined by continuous extraction in a Soxhlet apparatus for $8 \mathrm{~h}$ using hexane as solvent (AOAC, 1990). Carbohydrate content was determined through the method used by Samant and Rege (1989). Total ash was determined by incinerating in a furnace at $550^{\circ} \mathrm{C}$ (AOAC, 1990). Method described by Dubois et al. (1956) was used to determine total sugars while reducing sugars were analyzed according to the method of Bernfeld (1955) using 3.5 dinitrosalycilic acids (DNS). The crude fibre contents were determined according to standard method (AOAC, 1990).

The energy values of mushroom samples were evaluated using formula described by Crisan and Sands (1978).

$$
\begin{aligned}
\mathrm{EV} & =(2.62 \times \% \mathrm{P})+(8.37 \times \% \mathrm{~F})+(4.2 \times \% \mathrm{C}) \\
\mathrm{EV} & =\text { Energy value }(\mathrm{kcal} / 100 \mathrm{~g}) \\
\% \mathrm{P} & =\text { Protein } \\
\% \mathrm{~F} & =\text { Fat } \\
\% \mathrm{C} & =\text { Carbohydrate }
\end{aligned}
$$

\section{Mineral Analysis}

Minerals were determined employing AOAC (1990) method. Flour was digested with a mixture of concentrated nitric acid (14.44 mol/L), sulfuric acid (18.01 mol/L), perchloric acid $(11.80 \mathrm{~mol} / \mathrm{L})$ and analyzed using an atomic absorption spectrophotometer. The total phosphorus was determined as orthophosphate by the ascorbic acid method after acid digestion and neutralization using phenolphthalein indicator and combined reagent (APHA, 1995).

\section{Amino Acid Composition}

Total amino acid composition of samples was determined after hydrolysis in $6 \mathrm{M} \mathrm{HCl}$ with phenol (1\%) at $150^{\circ} \mathrm{C}$ for $60 \mathrm{~min}$, in Pico-Tag system (Waters, Milford, Mass., USA). The phenylisothiocyanate (PITC®) amino acid derivatives were eluted on HPLC Applied Biosystems Model 172 A (Applera Corp, Foster City, Calif., U.S.A.) equipped with a PTC RP-18 column $(2.1 \mathrm{~mm} \times 22 \mathrm{~cm})$. Sodium acetate $(45 \mathrm{mM}, \mathrm{pH} 5.9$ and $105 \mathrm{mM}, \mathrm{pH} 4.6 ; 30 \%)$, and acetonitrile $(70 \%)$ were used as buffers.

\section{Statistical Analysis}

All chemical analyses and assays were performed in triplicate, unless otherwise indicated. Results were expressed as mean values \pm standard deviation (SD). Analysis of variance (ANOVA) followed by Duncan's test was performed to test for differences between means by employing Kyplot (version 2.0 beta 15, c1997-2001, Koichi Yoshioka) statistical software. Significance of differences was defined at the $5 \%$ level $(\mathrm{P}<0.05)$.

\section{Results and Discussion}

\section{Proximate Composition}

The results of the proximate composition of the mushroom samples are presented in Table 1. The moisture content of all studied mushroom species ranged from $85.06 \pm 1.63 \%$ to $85.23 \pm 0.98 \%$ with the lowest amount of dry matter ranged from $14.77 \pm 0.94 \%$ to $14.94 \pm 0.93 \%$. This high moisture content was an indication that fresh mushrooms cannot keep for long time. This is because high water activity enhances microbial growth (Brock et al. 1986). Similar observation was made by Heleno et al. (2009) for Lactarius salmonicolor and R. delica.

Edible mushrooms are highly valued as a good source of carbohydrates and their contents usually range from $28.38 \%$ to $82.8 \%$ of dry weight (dw) (Thatoi and Singdevsachan, 2014). In the present study, the highest carbohydrate contents ranged from $33.23 \%$ to $42.44 \% \mathrm{dw}$. The relatively high carbohydrate content recorded in the samples (Table 2) was a proof of their being highly nutritious and good for human consumption.

The value of crude fat content and soluble sugar of the collected mushrooms were generally low. This suggests that diabetics and those with heart or weight problems can consume wild edible mushrooms (Chan, 1981).

The ash content was ranged from $12.7 \pm 0.16 \%$ to $13.80 \pm 0.10 \% \mathrm{dw}$. This ash content was higher compared to those reported by Agrahar-Murugkar and Subbulakshmi (2005) on Russula integra (11.5\%) and Akata et al. (2012) on Russula anthracina (7.71\%).

In the present study, the fibre content was ranged from $9.59 \pm 0.21 \%$ to $19.78 \pm 0.7 \% \mathrm{dw}$. This result was similar to that reported by Pushpa and Purushothama (2010) on $R$. delica and Agaricus bisporus. This finding is important because crude fibre has useful role in providing roughage that aids digestion and reduces the risks of cardiovascular diseases. Fibre consumption also soften stools and lowers plasma cholesterol level in the body (Verma and Banerjee, 2010). 
Protein content, with its sufficiency in a diet indicating its adequacy and quality was found to range from $38.08 \pm 0.29$ to $38.52 \pm 0.23 \%$ dw among the mushrooms studied. This result was in agreement with those reported by Pushpa and Purushothama (2010) for five mushrooms, Manjunathan et al. (2011) for four wild mushrooms, Tamil Nadu and Kumar et al. (2013) for 15 selected mushrooms of Nagaland. Hence, the mushrooms of this study can be eaten as a protein supplement or as an alternative to fish and meat in rural areas where these foods are very expensive for the population. Vegetarians could also eat mushrooms because it served as alternative protein supplements in their diet. Mushroom proteins are generally higher than those of green vegetables and oranges (Chan, 1981).

\section{Mineral Composition}

Mineral elements are essential for human health. The concentration of elements has an important physiological effect on different organs and cellular mechanisms (Vetter 2003); therefore, it is necessary to know the levels of essential elements in mushrooms before using them. The mineral composition of these mushrooms was shown in Table 2. This study indicated that the mushrooms were specifically rich in potassium, phosphorus, calcium and magnesium. Significant differences were observed between the three mushrooms concerning mineral contents $(\mathrm{P}=0.05)$. Their high contents in these mushrooms may be due to the absorption and accumulation of these elements from their habitat. $R$. delica contained the highest levels of calcium and phosphorus compared to other mushrooms. However, $R$. lepida contained the highest values of $\mathrm{K}$ and $\mathrm{Mg}$ compared to other mushrooms.

The K/Na ratio (6.30) of $R$. lepida was close to the recommended 5.0 (Szentmihalyi et al., 1998). Dietary changes leading to reduce consumption of potassium than sodium have health implications. Diets with higher ratio of $\mathrm{K} / \mathrm{Na}$ are recommended and these are found usually in whole foods (Arbeit et al., 1992). Foods naturally higher in potassium than sodium may have a $\mathrm{K} / \mathrm{Na}$ ratio of 4.0 or more (CIHFI, 2008). The high $\mathrm{K} / \mathrm{Na}$ suggests that this mushroom could be suitable in helping to ameliorate sodium-related health risk (Appiah et al., 2011). The $\mathrm{Ca} / \mathrm{P}$ ratio of $R$. mustelina and $R$. delica was 0.53 and 0.84 respectively, and was below 1 . However, according to SCSG (2007) a good menu should have a $\mathrm{Ca} / \mathrm{P}$ ratio over 1. Foods with high level in phosphorus and low level in calcium tend to make the body over acid deplete it of calcium and other minerals and increase the tendency towards inflammations (Appiah et al., 2011). In order to avoid this problem, these mushrooms need supplementation with calcium to prevent mineral and osmotic imbalance (Appiah et al., 2011).

Table 1 Proximate composition values of different Russula species

\begin{tabular}{|c|c|c|c|}
\hline \multirow{2}{*}{ Parameters } & \multicolumn{3}{|c|}{ Proximate composition values of different species } \\
\hline & R. lepida & R. mustelina & R. delica \\
\hline Moisture (\%) & $85.20 \pm 1.16^{\mathrm{a}}$ & $85.06 \pm 1.63^{\mathrm{a}}$ & $85.23 \pm 0.98^{\mathrm{a}}$ \\
\hline Dry matter $(\%)$ & $14.46 \pm 0.81^{\mathrm{a}}$ & $15.27 \pm 0.93^{\mathrm{a}}$ & $14.37 \pm 0.94^{\mathrm{a}}$ \\
\hline Fibre $(\%)$ & $11.34 \pm 0.21^{\mathrm{b}}$ & $9.59 \pm 0.21^{\mathrm{a}}$ & $19.78 \pm 0.7^{\mathrm{c}}$ \\
\hline Crude protein $(\%)$ & $38.50 \pm 0.89^{\mathrm{b}}$ & $38.08 \pm 0.29^{\mathrm{a}}$ & $38.52 \pm 0.23^{\mathrm{b}}$ \\
\hline Crude fat $(\%)$ & $4.06 \pm 0.11^{\mathrm{a}}$ & $5.70 \pm 0.05^{\mathrm{c}}$ & $5.18 \pm 0.2^{\mathrm{b}}$ \\
\hline Carbohydrates $(\%)$ & $41.64 \pm 1.41^{\mathrm{c}}$ & $41.11 \pm 0.92^{\mathrm{b}}$ & $39.29 \pm 1.71^{\mathrm{a}}$ \\
\hline Total ash $(\%)$ & $12.89 \pm 0.22^{\mathrm{a}}$ & $12.7 \pm 0.16^{\mathrm{a}}$ & $13.80 \pm 0.10^{\mathrm{b}}$ \\
\hline Reducing sugars $(\%)$ & $0.48 \pm 0.02^{\mathrm{a}}$ & $0.40 \pm 0.02^{\mathrm{a}}$ & $0.84 \pm 0.12^{\mathrm{b}}$ \\
\hline Total sugars $(\%)$ & $18.00 \pm 0.36^{\mathrm{b}}$ & $18.27 \pm 0.26^{\mathrm{b}}$ & $17.07 \pm 0.27^{\mathrm{a}}$ \\
\hline Energy value (kcal/100g) & $309.74 \pm 3.7^{\mathrm{b}}$ & $320.14 \pm 2.25^{\mathrm{c}}$ & $309.29 \pm 3.35^{\mathrm{a}}$ \\
\hline
\end{tabular}

Table 2 Mineral content of different Russula species

\begin{tabular}{l|ccc}
\hline \multirow{2}{*}{ Mineral elements } & \multicolumn{3}{c}{ Mineral content of different species (mg/100 g of dry weight product) } \\
\cline { 2 - 4 } & R. lepida & R. mustelina & R. delica \\
\hline $\mathrm{Ca}$ & $270 \pm 1.71^{\mathrm{b}}$ & $127 \pm 0.87^{\mathrm{a}}$ & $370 \pm 2.41^{\mathrm{c}}$ \\
$\mathrm{P}$ & $147 \pm 1.44^{\mathrm{a}}$ & $240 \pm 2.02^{\mathrm{b}}$ & $440 \pm 2.35^{\mathrm{c}}$ \\
$\mathrm{Fe}$ & $50.6 \pm 1.17^{\mathrm{b}}$ & $18.4 \pm 0.63^{\mathrm{a}}$ & $56.2 \pm 0.68^{\mathrm{c}}$ \\
$\mathrm{Mn}$ & $7.28 \pm 0.08^{\mathrm{c}}$ & $6.27 \pm 0.10^{\mathrm{b}}$ & $4.41 \pm 0.32^{\mathrm{a}}$ \\
$\mathrm{Cu}$ & $1.70 \pm 0.01^{\mathrm{a}}$ & $3.33 \pm 0.02^{\mathrm{c}}$ & $2.30 \pm 0.15^{\mathrm{b}}$ \\
$\mathrm{Zn}$ & $9.5 \pm 0.27^{\mathrm{b}}$ & $6.32 \pm 0.03^{\mathrm{a}}$ & $10.5 \pm 0.16^{\mathrm{c}}$ \\
$\mathrm{Na}$ & $65 \pm 0.36^{\mathrm{c}}$ & $56 \pm 0.26^{\mathrm{b}}$ & $50.6 \pm 1.16^{\mathrm{a}}$ \\
$\mathrm{K}$ & $410 \pm 3.50^{\mathrm{c}}$ & $85 \pm 0.23^{\mathrm{a}}$ & $91 \pm 1.15^{\mathrm{b}}$ \\
$\mathrm{Mg}$ & $327 \pm 1.61^{\mathrm{b}}$ & $252 \pm 2.04^{\mathrm{c}}$ & $30.7 \pm 0.10^{\mathrm{a}}$ \\
$\mathrm{Se}$ & $\mathrm{ND}$ & $\mathrm{ND}$ & $2.69 \pm 0.01^{\mathrm{a}}$ \\
$\mathrm{Ca} / \mathrm{P}$ & 1.84 & 0.53 & 0.84 \\
$\mathrm{~K} / \mathrm{Na}$ & 6.30 & 1.52 & 1.82 \\
\hline $\mathrm{Ea}$ & & & \\
\hline
\end{tabular}

Each value is an average of three replicate, Values are mean \pm standard deviation, Means not sharing a similar letter in a line are significantly different $\mathrm{P} \leq 0.05$ as assessed by the test of Duncan. ND: Not Detected 
Table 3 Amino acid content of different Russula species

\begin{tabular}{|c|c|c|c|}
\hline \multirow{2}{*}{ Amino acid type } & \multicolumn{3}{|c|}{ Amino acid content of different species (g/100g of protein) } \\
\hline & R. lepida & R. mustelina & R.delica \\
\hline Leucine $^{*}$ & $4.7 \pm 0.1^{\mathrm{a}}$ & $5.19 \pm 0.06^{\mathrm{c}}$ & $4.5 \pm 0.52^{\mathrm{a}}$ \\
\hline Isoleucine* & $5.06 \pm 0.04^{\mathrm{b}}$ & $3.31 \pm 0.16^{\mathrm{a}}$ & $3.42 \pm 0.13^{\mathrm{a}}$ \\
\hline Valine* & $6.17 \pm 0.04^{\mathrm{b}}$ & $5.82 \pm 0.04^{\mathrm{a}}$ & $8.32 \pm 0.21^{\mathrm{c}}$ \\
\hline Tryptophane* & $1.33 \pm 0.21^{\mathrm{a}}$ & $1.1 \pm 0.02^{\mathrm{a}}$ & $1.4 \pm 0.14^{\mathrm{a}}$ \\
\hline Lysine* & $3.9 \pm 0.2^{\mathrm{b}}$ & $5.68 \pm 0.02^{\mathrm{c}}$ & $2.68 \pm 0.05^{\mathrm{a}}$ \\
\hline Thréonine* & $2.98 \pm 0.02^{\mathrm{a}}$ & $2.5 \pm 0.05^{\mathrm{b}}$ & $3.22 \pm 0.31^{\mathrm{c}}$ \\
\hline Phenylalanine* & $0.71 \pm 0.04^{\mathrm{a}}$ & $5.61 \pm 0.17^{\mathrm{c}}$ & $2.8 \pm 0.18^{\mathrm{b}}$ \\
\hline Methionine* & $1.2 \pm 0.02^{\mathrm{c}}$ & $0.49 \pm 0.06^{\mathrm{b}}$ & $0.29 \pm 0.02^{\mathrm{a}}$ \\
\hline Histidine $*$ & $4.33 \pm 0.38^{\mathrm{c}}$ & $2.25 \pm 0.26^{\mathrm{a}}$ & $3.49 \pm 0.06^{\mathrm{b}}$ \\
\hline Arginine & $2.43 \pm 0.18^{\mathrm{a}}$ & $5.93 \pm 0.15^{\mathrm{b}}$ & $2.26 \pm 0.14^{\mathrm{a}}$ \\
\hline Alanine & $2.66 \pm 0.15^{\mathrm{c}}$ & $3.26 \pm 0.12^{\mathrm{b}}$ & $2.77 \pm 0.32^{\mathrm{a}}$ \\
\hline Proline & $0.29 \pm 0.02^{\mathrm{a}}$ & $0.34 \pm 0.03^{\mathrm{b}}$ & $0.28 \pm 0.01^{\mathrm{a}}$ \\
\hline Aspartic acid & $5.93 \pm 0.14^{\mathrm{c}}$ & $3.01 \pm 0.03^{\mathrm{a}}$ & $5.63 \pm 0.05^{\mathrm{b}}$ \\
\hline Glycine & $6.46 \pm 0.2^{\mathrm{b}}$ & $4.52 \pm 0.08^{\mathrm{a}}$ & $6.29 \pm 0.27^{\mathrm{c}}$ \\
\hline Tyrosine & $0.16 \pm 0.03^{\mathrm{a}}$ & $0.21 \pm 0.02^{\mathrm{b}}$ & $0.18 \pm 0.03^{\mathrm{ab}}$ \\
\hline Serine & $6.02 \pm 0.08^{\mathrm{b}}$ & $6.07 \pm 0.09^{\mathrm{b}}$ & $5.63 \pm 0.05^{\mathrm{a}}$ \\
\hline Glutamic acid & $13.92 \pm 1.04^{\mathrm{a}}$ & $15.22 \pm 0.72^{\mathrm{a}}$ & $15 \pm 0.4^{\mathrm{a}}$ \\
\hline Cystine & $5.41 \pm 0.05^{\mathrm{b}}$ & $0.58 \pm 0.06^{\mathrm{a}}$ & $5.93 \pm 0.15^{\mathrm{c}}$ \\
\hline Total essential amino acids & $29.41 \pm 2.19^{\mathrm{a}}$ & $33.98 \pm 3.28^{\mathrm{a}}$ & $30.32 \pm 1.96^{\mathrm{a}}$ \\
\hline
\end{tabular}

\section{Amino Acid Composition}

The amino acid profile of these mushrooms was shown in Table 3. Among the amino acids, 18 were determined, and the most predominant ones were glutamic acid and valine in the all species. This was in agreement with those reported by Ribeiro et al. (2008) and Beluhan and Ranogajec (2011). The results suggested that these mushrooms were rich in essential amino acids. The ratios of essential amino acids to total amino acids were 0.40 to 0.45 and may well meet the minimum daily requirements (WHO, 1975). The quality of a food protein depend largely on its amino acid content. The cells, in making their own protein, need a full array of amino acids from food. Cells can synthesize non-essential amino acids when they are unavailable from food, but essential amino acids can only be obtained from foods (Sizer and Whitney, 2000). The high scores of essential amino acids present in these mushrooms implied that they have a high biological protein value. This was particularly important as there was a need for novel protein sources owning to the increasing cost of conventional sources of protein in the third world. In addition, the cereal based diets common in developing countries could receive a boost with the inclusion of these mushrooms in their diet.

\section{Conclusion}

Results from the present study indicated that the three wild edible mushrooms species of Russula from avarious locations across center region (Côte d'Ivoire) were rich in nutrients including protein, carbohydrates, fibre, especially essential amino acids and minerals. Our micronutrient values were in agreement with reports in the literature. So, it can be said that these determinations make the investigated wild edible mushroom popular and easily able to consume. Therefore, these mushrooms could be considered a potential health food and may be of use to the food industry as a source of ingredients with high nutritional value.

\section{Acknowledgments}

We also express our gratitude to Dr. Ir. Nourou S. YOROU (University of Munich, Tropical Mycology, Department Biology I, Organismic Biology, Germany) for contribution on identification of the three edible mushrooms used in the present study.

\section{References}

Agerer R. 2002. Color Atlas of Ectomycorrhiza. 12th divelery, EinhornVerlag Edward, Dientenurger, Germany.

Agrahar-Murugkar D, Subbulakshmi G. 2005. Nutritional value of edible wild mushrooms collected from the Khasi hills Meghalaya. Food Chem, 89: 599-603.

Akata I, Ergönül B, Kalyoncu F. 2012. Chemical Composition and Antioxidant Activities of 16 Wild Edible Mushroom Species Grown in Anatolia. Int J Pharmacol, 8(2): 134-138.

AOAC. 1990. Official Methods of Analysis. 15th E dn., Association Official Analytical Chemists. Washington DC.

AOAC. 1995. Official Method of Analysis. Association of Agricultural Chemist, Washington DC.

APHA. 1995. Standard methods for examination of water and waste water, 19th ed., American Public Health Association, USA.

Appiah F, Oduro I, Ellis WO. 2011. Proximate and mineral composition of Artocarpus altilis pulp flour as affected by fermentation. Pak J Nutr, 10(7): 653-657.

Arbeit ML, Nicklas TA, Berenson GS. 1992. Considerations of dietary sodium/potassium/energy ratios of selected foods. J Am Coll Nutr, 11: 210-222.

Beluhan S, Ranogajec A. 2011. Chemical composition and nonvolatile components of Croatian wild edible mushrooms. Food Chem, 124: 1076-1082. 
Bernfeld P. 1955. Amylase $\alpha$ and $\beta$. Methods in enzymology 1.S. P. Colswick and N.O.K., Ed. Academic Press Inc, New-York, 149154.

Brock OT, Thomas K, Brock M, David MW. 1986. Basic Microbiology with Applications. Antibiotics and other chemotherapeutic agents 3rdEdn, 144-155.

Chan HKM. 1981. Consumption of edible mushrooms in Hong Kong. Mushrooms News letter Tropics, 1: 5-10.

CIHFI. 2008. Potassium/sodium ratio (K/Na ratio). The Center for the Improvement of Human Functioning International. Wichita, USA. Retrieved from: http: //biocenterlab. org/tests/urine/kna.shtml, (Accessed on: January 15, 2015).

Crisan EV, Sands A. 1978. The biology and cultivation of edible mushrooms, Nutritional value, Academic Press, New York, 137-168.

Das K. 2010. Diversity and conservation of wild mushrooms in Sikkim with special reference to Barsey Rhododendron Sanctuary. NeBIO, 1(2):1-13.

Dubois M, Gilles KA, Hamilton JK, Rebers PA, Smith F. 1956 Colorimetric method for determination of sugars and related substances. Anal Chem, 28: 350-356.

Gbolagade J, Ajayi A, Oku I, Wankasi D. 2006. Nutritive Value of Common Wild Edible Mushrooms from Southern Nigeria. Global J Biotechnol Biochem, 1(1): 16-21.

Hawksworth DL. 2001. Mushrooms: the extent of the unexplored potential. Int J Med Mushr, 3: 333-337.

Heleno SA, Barros L, Sousa MJ, Martins A, Ferreira ICFR. 2009. Study and characterization of selected nutrients in wild mushrooms from Portugal by gas chromatography and high performance liquid chromatography. Microchem J, 93(2): 195199.

Jain N, Pande V. 2013. Antimicrobial activity of ectomycorrhizal species; Russula delica and Scleroderma areolatum. Indian J Appl Microbiol, 16(1): 13-20.

Jonathan SG, Fasidi IO. 2005. Antimicrobial activities of some selected Nigerian mushrooms. Afr J Biomed Res, 8: 83-87.

Koné, NA, Yéo K, KonatéK S, Linsenmair E. 2013. Socioeconomical aspects of the exploitation of Termitomyces fruit bodies in central and southern Côte d'Ivoire: Raising awareness for their sustainable use. J Appl Biosci, 70: 5580-5590.

Kraigher H, Agerer R, Javornik. B. 1995. Ectomycorrhizae of Lactarius lygniotus on Norway spruce, characterized by anatomical and molecular tools. Mycorrhiza, 5: 175-180.

Kuforiji OO, Fasidi IO, Odunfa SA. 2003. Nutritive value of Pleurotus tuber-regium cultivated on different Agro-industrial wastes. Nig J Microbiol, 17: 63-67.

Kumar R, Tapwal A, Pandey S, K.Borah R, Borah D, Borgohain J. 2013. Macro-fungal diversity and nutrient content of some edible mushrooms of Nagaland, India. Nusantara Biosci, 5(1):17.

Liu Jk. 2007. Secondary metabolites from higher fungi in China and their biological activity. Drug Discov Ther, 1(2): 94-103.
Manjunathan J, Subbulakshmi N, Shanmugapriya R, Kaviyarasan V. 2011. Proximate and mineral composition of four edible mushroom species from South India Int J Biodivers Conserv, 3(8):386-388.

Manzi P, Gambelli L, Marconi S, Vivanti V Pizzoferrato L. 1999. Nutrients in edible mushrooms: An interspecies comparative study. Food Chem, 65: 477-482.

Marx DH. 1997. Forest application of ectomycorrhizal fungus Pisolithus tinctorius. The Marcus Wallenberg foundation, Sweden.

Mercan N, Duru ME, Türkoğlu A, Gezer K, Kıvrak İ, Türkoğlu H. 2006. Antioxidant and antimicrobial properties of ethanolic extract from Lepista nuda (Bull.) Cooke. Ann Microbiol, 56(4): 339-344.

Molina R, Trappe JM. 1982. Patterns of ectomycorrhizal host specificity and potential among pacific northwest conifers and fungi. For Sci, 28: 423-458.

Pushpa H, Purushothama KB. 2010. Nutritional Analysis of Wild and cultivated Edible Medicinal Mushrooms. World J and Food Sci, 5(2): 140-144.

Ribeiro B, Andrade PB, Silva BM, Baptista P, Seabra RM, Valentão P. 2008. Comparative study on free amino acid composition of wild edible mushrooms species. J. Agric and Food Chem, 56: 10973-10979.

Rinaldi AC, Comandino O, W.Kuyper T. 2008. Ectomycorrhizal fungal diversity: separating the wheat from chaff. Fungal Diver, 33: $1-45$.

Samant SK, Rege DV. 1989. Carbohydrate Composition of Some Cucurbit Seeds. J Food Comp and Analysis, 2: 149-156.

SCSG. 2007. Calcium to Phosphorus Ratios in Food. Glider Vet. Sun Coast Sugar Gliders. Retrieve from: http://www.sugargliders.com/glidervet-60.htm, (Accessed on: January 15, 2015.

Sizer F, Whitney E. 2000. Nutrition concept and controversies (Eight Ed.) Wadsworth, a Division of Thomson Learning Inc., USA.

Szentmihalyi K, Kery A, Then M, Lakatos B, Sandor Z, Vinkler P. 1998. Potassium-sodium ratio for the characterization of medicinal plant extracts with diuretic activity. Phytother Res, 12: $163-166$.

Thatoi H, Singdevsachan SK. 2014. Diversity, nutritional composition and medicinal potential of Indian mushrooms: A review. Afr J Biotechnol, 13(4): 523-545.

Verma AK, Banerjee R. 2010. Dietary fibre as functional ingredient in meat products: a novel approach for healthy living a review. $\mathrm{J}$ Food Sci Tech, 47(3): 247-257.

Vetter J. 2003. Data on sodium content of common edible mushrooms. Food Chem, 81: 589-593.

WHO. 1975. Energy and Protein Requirements. WHO Technical Report, 522p. 